\title{
Taxation of internet gaming and gambling in the European Union
}

\author{
Prof. René N.G. van der Paardt
}

Published online: 21 January 2010

(C) The Author(s) 2010. This article is published with open access at Springerlink.com

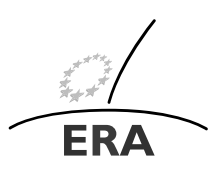

EUROPÄISCHE RECHTSAKADEMIE ACADEMY OF EUROPEAN LAW ACADEMIE DE DROIT EUROPEEN ACCADEMIA DI DIRITTO EUROPEO TRIER - TREVES - TREVIRI

\begin{abstract}
One of the major issues in cross-border internet gambling is taxation of gambling services. The question arises of how to levy VAT and/or betting and gambling taxes on such gambling services in the country of destination. The article addresses this question and examines how VAT will be levied in an EU without borders for services. In addition a brief outline also looks at the way the Dutch betting and gambling tax deals with this phenomenon.
\end{abstract}

Keywords Gambling tax · One-stop shop system · Online gaming · EU VAT

\section{Introduction}

Betting and gambling is a fact of life. Whether or not betting and gambling is regulated, or is considered to be illegal in general or only considered legal when operated by certain (state) companies and considered illegal when operated by non regulated persons, companies or institutions, all forms of betting and gambling are treated alike from a tax point of view. Most countries levy a specific betting and gambling tax and these countries have created a broad taxable base to include both resident and nonresident companies for paying the tax when resident players receive income from betting and gambling.

This is the written version of the presentation given by the author at the conference on "Gambling in the Internal Market-Balancing state and stakeholders' interests", organised by ERA in cooperation with the Czech Presidency of the Council of the European Union on 15-16 June 2009 in Prague.

R.N.G. van der Paardt $(\bowtie)$

Erasmus University Rotterdam, Loyens \& Loeff N.V. Tax lawyers, Weena 690, 3012 Rotterdam, Netherlands

e-mail: rene.van.der.paardt@loyensloeff.com 
Also, in most countries, services provided by companies to residents and leading to consumption are subject to a (general) consumption tax such as VAT (value added tax), GST (goods and services tax) or sales tax. In these consumption taxes there is a broad definition of taxable services. For example in EU VAT, any transaction between companies for a consideration other than the supply of goods is regarded as a (taxable) service. Because of this broad definition an exemption is included in the VAT law in case a country levies a special betting and gambling tax. For instance in article 135 (1) i of the European VAT Directive ${ }^{1}$ (which should be implemented in all 27 Member States) an exemption is provided for "betting, lotteries and other forms of gambling, subject to the conditions and limitations laid down by each Member State". In most EU countries this exemption is implemented.

This exemption is limited to betting, lotteries and gambling, which implies that games that do not fall under this definition, such as pinball machines and all kind of internet games, are subject to VAT.

Since gambling as well as games are not only supplied locally by stores or local betting and lottery operators but also by companies based in other jurisdictions and via the internet, the question arises of how to tax these games and gambling either with VAT or a betting and gambling tax.

In the following paragraphs is explained how VAT is levied in the EU countries in a world without borders for services. A brief outline will present the way the Dutch betting and gambling tax deals with this phenomenon before conclusions will be offered.

\section{EU VAT on electronic services in a world without borders}

In general for services that are supplied from business to business (B2B) VAT is levied in the country of the purchaser of the service and since this purchaser is a VAT registered company the liability to file the VAT return and pay the VAT is shifted to this purchaser (the so called reverse charge). In case the purchaser is allowed to deduct the VAT paid, the reverse charge VAT due can be offset against the credit of the same VAT (as input VAT) and in the end the VAT on services acquired abroad does not have financial implications. Although there are and will be (after 1.1.2010) exceptions to this rule for B2B transactions, VAT is in general only an administrative burden. $^{2}$

For services rendered to consumers the situation is more complex. The existing main rule is that these services are taxable in the country where the supplier of the services is situated. But there are a lot of exceptions to this rule in order to tax the services in the country where the customer lives and uses the services. For EU inbound services the rules attempt to tax these services in the same way as locally acquired services in order to avoid unequal competition. Services supplied to customers outside the EU are not taxable in the EU country of the supplier but in the place of the

\footnotetext{
${ }^{1}$ Directive 2006/112/EC of the Council (OJL 347/1).

${ }^{2}$ Except for companies that are not or not fully allowed to deduct input VAT such as financial institutions, insurance companies, holding companies, social-, healthcare- and educational institutions.
} 
customer (whether or not the services are effectively subject to GST or VAT) in that country.

For electronically supplied B2C services, in the present situation the main rule is that these services are taxable in the place of the supplier of the services. Non-EU providers supplying these services to non-taxable persons in the EU are however already liable for VAT in the Member States where the customers are established or reside. To avoid the need for multiple VAT registrations, non-EU suppliers can make use of the "one-stop-shop" scheme that allows them to register for VAT purposes in a single Member State from which they can deal with all their EU VAT compliance and reporting requirements. The Member State where the non-EU supplier is registered transfers the VAT collected to those Member States where the customers are established or reside. For EU providers, the current place of supply rule is the default rule, i.e. where the supplier of the services is established. Consequently, it may be beneficial to be established in a country with a low VAT rate. Also for the same reasons it can be advantageous for companies outside the EU to establish a subsidiary or a branch in an EU country with a low VAT-rate.

After 1.1.2010 for most services, the place of taxation will continue to be that where the supplier is established, as at present; however, in certain circumstances, taxation of business-to-consumer services will be in the place of consumption in order to prevent distortions of competition between Member States operating different VAT rates. This category includes: restaurant services; the hiring of means of transport; cultural, sporting, scientific and educational services and telecommunications, broadcasting and electronic services. Furthermore a "one-stop shop" system will be introduced for telecom, broadcasting and electronic services in order to simplify arrangements made necessary by the new rules. The "one-stop shop" will enable service providers to fulfil in their home Member State a single set of obligations for VAT registration, declarations and payments, covering services provided in Member States where they are not established. VAT revenue will then be transferred from the country where the supplier is located to that where the customer is situated, whose VAT rates and controls will be applicable. For business-to-consumer supplies of telecoms, broadcasting and electronic services, application of the new rules and the one-stop shop scheme will be deferred until 1 January 2015. The Member State of establishment will, until 1 January 2019, retain a proportion of VAT receipts collected through the one stop shop scheme. This proportion will amount to $30 \%$ from 1 January 2015 until 31 December 2016, 15\% from 1 January 2017 until 31 December 2018 and $0 \%$ from 1 January 2019 onwards.

Therefore from 1 January 2015 onwards, the rules applicable to digitised services supplied at a distance will change. Electronic, telecom and broadcasting services will be deemed to be supplied where the customer is established, has his usual address or resides (whether the customer is a business or a consumer), and the same rules will similarly apply to non-EU service providers and EU service providers. Electronically supplied services cover services with internet content, not mere communication by email. Non-EU service providers supplying telecoms, radio and television and broadcasting services to non-taxable persons resident in the European Union will be able to register in a single Member State of their choice such as today (a mini one-stop shop arrangement), and the VAT will be charged at the rate applicable to the Member 
State of the customer. EU-based providers of electronically supplied services, telecoms, radio and television broadcasting services to consumers will also be able to fulfil all their VAT obligations in the Member State in which they are situated but the VAT rate charged will again be that applicable to the Member State of the customers. Electronic VAT returns will be required every quarter, showing the total value of relevant supplies and the total amount per rate of applicable VAT, split up country by country, possibly with 27 columns on each return! Payment of VAT will be made in Euros to a designated bank account. Input tax reclaims will be dealt with separately under the $8^{\text {th }}$ Reclaims Directive. Records will need to be kept for ten years.

For B2C electronic services supplied by providers established in the EU to customers outside the EU the possibility remains to treat them as taxable in the place where the customer is established or lives. In that case no EU VAT will be due and the country of the customer can charge GST or VAT on the supplied services.

\section{Conclusion}

Therefore the general conclusion is that electronic services including internet games are subject to EU VAT and at present in most cases VAT is due in the EU country where the supplier is situated or has a permanent establishment. For non EU based suppliers the VAT is due in the country where the customer acquires the online gaming service. After 1.1.2015 the VAT will be due in the country where the customers are situated also for companies established in the EU. To make things easy the mini one stop shop programme will make it possible to fulfil all VAT formalities in one EU country.

In the final situation there will be no difference in VAT between locally supplied gaming services and gaming services supplied by on line suppliers through the internet no matter where these suppliers are located, situated or established. In most EU countries there is no (joint) liability for the consumers to pay the VAT due to the suppliers of electronic services. The EU countries support the working of the mini one stop shop system and the fact that non EU suppliers might also benefit from the refund of input VAT paid in EU countries encourage them to register for VAT in the EU.

\section{Gambling tax}

As pointed out, betting and gambling are not subject to VAT and benefit from an exemption in the EU. In most countries a special betting and gambling tax is applicable. For these taxes, the taxable base is not the income of the supplier but the earnings of the prize winners. The prizes are part of the income of these private individuals and therefore the betting and gambling tax is a portion of these special earnings of the taxpayers. In most cases the tax is paid by the betting and gambling organisations as a kind of withholding tax, but in some cases the prize winners are themselves liable for paying the tax. 
In case of registered organisations licensed by the State or other governments, the withholding of the betting and gambling tax will be a simple way to fill the treasury. But in case of online betting and gambling the organiser of the gambling site can be situated anywhere and levying the tax is a bit more problematic. But as mentioned before, the way VAT is levied could also be a method of dealing with the betting and gambling tax.

As an example of how the betting and gambling tax is dealt with in respect of internet gambling a few remarks can be made about the Dutch betting and gambling tax.

\section{Dutch gambling tax}

An amendment to the Dutch Betting and Gambling Tax Act concerning online gambling came into force on 3 October 2008. With this amendment, the government wanted to implement a tax specifically geared towards illegal activities. It seems however that the amended gambling tax is effectively difficult to put into practice, particularly as far as determining who the actual taxpayer is.

The gambling tax (article 1) is levied (amongst others) on: "those providing the opportunity to participate in domestic online games of chance", and "the prize winners of online foreign games of chance residing in or established within the Netherlands". The tax rate is $29 \%$, per period, on the bets received less the prizes made available (the host's gross gaming yield) by those hosting the domestic online games of chance. On the basis of Article 5a of the Betting and Gaming Tax Act, the host may set-off any losses incurred in one period against any gains earned in subsequent periods.

Prize winners of foreign online games of chance residing in the Netherlands are liable for a gaming tax at a rate of $29 \%$, insofar as the balance between the gains taken during a given month and the bets placed during that month is positive. There is no tax liability if the balance is negative. The fact that there is no possibility to setoff losses in subsequent periods whilst a set-off is possible with respect to domestic online gambling appears to be in contravention of the EC Treaty. Hosts are not liable for tax if they provide the opportunity to participate in foreign online gambling. The consequence of this could be that players will seek to participate in national online gambling whilst hosts will strive to provide foreign online gambling to avoid the gambling tax in the Netherlands.

Foreign games of chance are all games of chance that are not regarded as domestic games of chance. A game of chance is deemed a domestic game of chance if it is operated by natural persons or entities, one or more of which reside or are established in the Netherlands. Should an online game of chance be jointly hosted by an entity established in the Netherlands and an entity established abroad, which entity is liable for tax? The State Secretary has supplied a number of tools to decide whether or not a game is domestic. The tools are (1) the language of the host's website; (2) the web address of the host's website; (3) the "provider" of the host's website; (4) all other information referred to on the host's website. The State Secretary has put forward a different view by stating that games of chance accessible via the internet in the Netherlands are deemed to be domestic games of chance. 
It seems that the Dutch gambling tax will be imposed on all foreign online gaming operators if the games of chance provided are accessible in the Netherlands. Although the concept "provision of opportunity" also exists in the Betting and Gaming Tax Act, this Act, contrary to the Betting and Gaming Act, specifically defines the concept of the domestic games of chance. Therefore in my opinion we should stick to the law itself and the domestic games are therefore only games of chance if they are operated by natural persons or entities, one or more of which reside or are established in the Netherlands.

The tax should be paid by the operating company that is liable to pay the prize to the winners, and these operators should register, keep records and file tax returns. But in case of prize winners of foreign games of chance (excluding online gambling) residing in or established within the Netherlands, the tax should be paid by the prize winners at the moment the prize is paid, received or can be won. For domestic prize winners of foreign online games of chance the tax should be paid by the prize winners at the end of each month where the payments for bets can be offset against the prizes received.

\section{Conclusion}

The legislator has chosen the approach to tax the domestic and foreign operators of betting and gambling but in case of online betting and gambling it has also made it possible to tax the prize winners. The question of whether this leads to a $100 \%$ income of all tax that could be levied cannot be answered and it is at least doubtful if levying tax from prize winners will lead to any tax income at all.

\section{General conclusion and final remarks}

Therefore the general conclusion is that electronic services including internet games are subject to EU VAT in the country where the consumer resides in case non EU traders provide such services to consumers in the EU and after 1.1.2015 the VAT will also be due for companies established within the EU in the country where the customers are situated. To make things easy the mini one stop shop programme will make it possible to fulfil all VAT formalities in one EU country. In the final situation there will be no difference in VAT between locally supplied gaming services and gaming services supplied by on line suppliers through the internet no matter where these suppliers are located, situated or established. In most EU countries there is no (joint) liability for the consumers to pay for the VAT the suppliers of electronic services are due to pay. The EU countries support the working of the mini one stop shop system and the fact that non EU suppliers might also benefit from the refund of input VAT paid in EU countries encourage them to register for VAT in the EU.

As far as betting and gambling taxes are concerned, there is a variety of taxes and sometimes only legal betting and gambling activities are taxable while illegal ones (specially the online ones) are considered non existing and therefore not taxable. 
In some countries such as the Netherlands, legislation provides for taxation of online betting and gambling also when provided by foreign suppliers. In such cases the prize winners are also regarded as taxable persons in order that they pay the tax themselves (supposing the foreign providers cannot be taxed). In my view the effectiveness of such an approach is doubtful and the way VAT is dealt with for non-resident service providers seems more promising.

Open Access This article is distributed under the terms of the Creative Commons Attribution Noncommercial License which permits any noncommercial use, distribution, and reproduction in any medium, provided the original author(s) and source are credited. 